\title{
Effects of Nighttime Ozone Treatment at Ambient Concentrations on Sensitive and Resistant Snap Bean Genotypes
}

\author{
Kirsten L. Lloyd ${ }^{1}$ \\ Department of Plant Science, The Pennsylvania State University, 102 Tyson Building, University \\ Park, PA 16802 \\ Donald D. Davis \\ Department of Plant Pathology and Environmental Microbiology, The Pennsylvania State University, \\ 211 Buckhout Laboratory, University Park, PA 16802
}

\author{
Richard P. Marini and Dennis R. Decoteau \\ Department of Plant Science, The Pennsylvania State University, 102 Tyson Building, University \\ Park, PA 16802
}

\begin{abstract}
AdDitional INDEX words. Phaseolus vulgaris, nocturnal stomatal conductance, R123, S156, biomonitor
Abstract. The effect of nighttime ozone $\left(\mathrm{O}_{3}\right)$ exposure, alone and in combination with daytime $\mathrm{O}_{3}$ treatment, was tested on yield of an $\mathrm{O}_{3}$-resistant (R123) and an $\mathrm{O}_{3}$-sensitive (S156) snap bean (Phaseolus vulgaris $\mathrm{L}$.) genotype. Three trials, with exposure durations ranging in length from 14 to 21 days, were conducted in continuous stirred tank

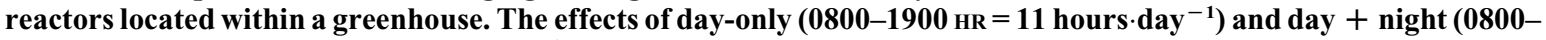
$1900 \mathrm{HR}+2000-0700 \mathrm{HR}=22$ hours $^{\left.-d_{a y}{ }^{-1}\right)}$ exposure timings were compared. The Fall 2014 trial also tested the effect of nighttime-only (2000-0700 $\mathrm{HR}=11$ hours $\left.\cdot \mathrm{day}^{-1}\right) \mathrm{O}_{3}$ exposure. Nighttime $\mathrm{O}_{3}$ exposure alone, at $62 \mathrm{ppb}$, did not cause foliar injury and had no effect on the yield of either genotype. In combination with daytime $\mathrm{O}_{3}$ exposure, nighttime $\mathrm{O}_{3}$ concentrations up to $78 \mathrm{ppb}$ did not impact yields or show a consistent effect on nocturnal stomatal conductance $\left(g_{\text {sn }}\right)$. When data were pooled across the day and day + night exposures times, mean daytime $\mathrm{O}_{3}$ levels $\geq 62$ ppb caused foliar injury and significant yield decreases in all three trials. Under control conditions, R123 and S156 produced similar pod masses in two of the three trials. In all three trials, R123 produced significantly greater yields by mass than $\mathrm{S} 156$ with elevated $\mathrm{O}_{3}$. Nighttime conductance measurements suggested that $\mathrm{S} 156$ and R123 have inherently different $g_{\text {sn }}$ rates and that cumulative $\mathrm{O}_{3}$ exposure can increase $g_{\mathrm{sn}}$ in both genotypes.
\end{abstract}

Across the globe, tropospheric ozone harms human and environmental health (World Health Organization, 2006), while also reducing crop yields (Ashmore, 2005). In the United States, the U.S. Environmental Protection Agency (USEPA) regulates $\mathrm{O}_{3}$ air pollution under the National Ambient Air Quality Standards (NAAQS). As a secondary air pollutant, $\mathrm{O}_{3}$ forms through photochemical reactions involving nitrogen oxides $\left(\mathrm{NO}_{\mathrm{x}}\right)$ and volatile organic compounds (VOCs), which are produced by anthropogenic and natural processes. Both $\mathrm{O}_{3}$ and its precursors migrate from urban sources to rural and remote locations, resulting in widespread impacts (USEPA, 2013).

Ambient $\mathrm{O}_{3}$ exposure contributes to yield losses for economically important plant species, including $\mathrm{O}_{3}$-sensitive cultivars of soybean [Glycine max (L.) Merr.], wheat (Triticum aestivum L.), potato (Solanum tuberosum L.), bean, tomato (Solanum lycopersicum L.), watermelon [Citrullus lanatus

Received for publication 31 Aug. 2017. Accepted for publication 15 Nov. 2017. Funding provided by the Pennsylvania Department of Environmental Protection, Bureau of Air Quality; the Pennsylvania Agricultural Experiment Station; and the Department of Plant Science, The Pennsylvania State University.

We thank Jim Savage, Jon Ferdinand, and Scott DiLoreto for their technical expertise; Kent Burkey for providing seed and expertise; Rick Bates and Jim Sellmer for reviewing the manuscript; and Martha Schupp and Emily Isaacs for greenhouse assistance.

${ }^{1}$ Corresponding author. E-mail: k1124@psu.edu.
(Thunb.) Matsum and Nakai], onion (Allium cepa L.), turnip (Brassica rapa L.), and lettuce (Lactuca sativa L.) (Booker et al., 2009; USEPA, 2013). Ozone, an oxidant gas, diffuses into leaves through stomatal pores and can either dissolve in water or react directly with biochemical compounds. The resulting reactive oxygen species damage membranes and other cell components, reducing photosynthesis, accelerating aging, and negatively affecting growth and reproduction (Booker et al., 2009; USEPA, 2013). Ozone exposure can also reduce crop quality and nutritive value (USEPA, 2015).

Sensitivity to $\mathrm{O}_{3}$ varies both within and among species. In general, plants that have higher stomatal conductance $\left(g_{\mathrm{s}}\right)$, which allows a greater flux of $\mathrm{O}_{3}$ into the leaf (Reich and Amundson, 1985; Temple, 1991), and lower levels of ascorbic acid, an antioxidant and key plant defense signaling molecule (Baier et al., 2005; Conklin and Barth, 2004), are more susceptible to injury. Within a species, different genotypes may vary in their molecular response to $\mathrm{O}_{3}$ (Baier et al., 2005; Gravano et al., 2004; Kangasjärvi et al., 2005; Langebartels et al., 2002; Pell et al., 1997; Schraudner et al., 1998; Wohlgemuth et al., 2002). In addition, environmental factors, such as light level and water availability, can interact with $\mathrm{O}_{3}$ stress and alter injury severity (Orvar et al., 1997; Wilkinson and Davies, 2010).

Booker et al. (2009) reviewed studies of $\mathrm{O}_{3}$ impacts on agronomic and horticultural crops, reporting yield losses 
ranging from $\approx 5 \%$ to $15 \%$ for $\mathrm{O}_{3}$ sensitive plants. Based on a meta-analysis of 81 publications, Feng and Kobayashi (2009) estimated that mean ambient $\mathrm{O}_{3}$ concentrations of 31-50 ppb, relative to base concentrations $(<26 \mathrm{ppb})$, reduced the yield of six major crops as follows: bean (19\%), rice [Oryza sativa L. (17.5\%)], wheat (9.7\%), barley [Hordeum vulgare L. (8.9\%)], soybean $(7.7 \%)$, and potato $(5.3 \%)$. Notably, plants may have been exposed to actual $\mathrm{O}_{3}$ concentrations in excess of $50 \mathrm{ppb}$ following the diurnal cycle of $\mathrm{O}_{3}$ over the 7- to 12-h averaging period. The USEPA's Clean Air Scientific Advisory Commission suggested that $\mathrm{O}_{3}$-induced crop yield reductions exceeding a threshold of 5\% relative loss are "unacceptably high," causing adverse impacts on public welfare (USEPA, 2015). Therefore, ambient $\mathrm{O}_{3}$ levels pose a definite concern to food production, and standards designed to protect vegetation require continual review.

In the latest revision of the NAAQS for $\mathrm{O}_{3}$, effective $28 \mathrm{Dec}$. 2015, the USEPA Administrator strengthened the secondary standard (i.e., protecting public welfare, including the yield and quality of agricultural crops) from 75 to $70 \mathrm{ppb}$. However, the legislation retains a "fourth-high metric" format and 8-h averaging time, identical to the primary standard used to protect public health (USEPA, 2015). In contrast to a cumulative exposure index, the fourth-high metric is based on the fourthhighest daily maximum $\mathrm{O}_{3}$ concentration (i.e., averaged over an 8-h period within a $24-\mathrm{h}$ window), averaged across three consecutive years.

The 70-ppb level of the fourth-high metric was correlated with the cumulative, concentration-weighted W126 index. The W126 takes into account all hourly $\mathrm{O}_{3}$ concentrations within the 12-h window from 0800 to 2000 HR (Lefohn et al., 1988; Lefohn and Runeckles, 1987; USEPA, 2015). Despite evidence showing injury due to nighttime $\mathrm{O}_{3}$ exposure (Goknur and Tibbitts, 2001; Lee and Hogsett, 1999; Matyssek et al., 1995; Winner at al., 1989), the 12-h W126 index does not include elevated $\mathrm{O}_{3}$ episodes occurring between 2000 and $0800 \mathrm{HR}$ (USEPA, 2015). Public comment on the proposed NAAQS for $\mathrm{O}_{3}$ suggested that the W126 cumulative index, as the sole calibration for the hourly maximum fourth-high metric, should include concentrations for the entire 24-h period within $1 \mathrm{~d}$ (USEPA, 2015; also see A.S.L. \& Associates, n.d.). Therefore, the 12-h W126, when calculated from 0800 to $2000 \mathrm{HR}$, may not adequately describe exposure-response relationships to protect sensitive vegetation where nighttime $\mathrm{O}_{3}$ exposure is a factor (Musselman et al., 2006).

Nocturnal stomatal conductance has been reported for a wide range of species (Caird et al., 2007; Dawson et al., 2007; Musselman and Minnick, 2000), demonstrating the potential for $\mathrm{O}_{3}$ uptake from ambient air at night. Furthermore, researchers observed injury resulting from nighttime or dark period $\mathrm{O}_{3}$ exposure, using both indoor (Goknur and Tibbitts, 2001) and outdoor chambers (Günthardt-Goerg, 1996; Lee and Hogsett, 1999; Matyssek et al., 1995). However, no clear nighttime exposure-response relationships have been developed for $\mathrm{O}_{3}$ to date, and evidence documenting the cumulative effects of nighttime $\mathrm{O}_{3}$ exposure remains limited (USEPA, 2013).

Nighttime $\mathrm{O}_{3}$ exposure occurs when $\mathrm{O}_{3}$ concentrations remain elevated in the surface layer of the atmosphere because of limited destruction via dry deposition and NO scavenging. Based on available monitoring data, the USEPA (2013) identified mountainous areas of southern California, the front-range of Colorado, and the Great Smoky Mountains as potential locations of concern for elevated nocturnal $\mathrm{O}_{3}$ levels. However, nighttime $\mathrm{O}_{3}$ exposure may cause injury in other locations. Typically, $\mathrm{O}_{3}$ is produced photochemically during daylight hours, reaching a peak in midafternoon and decreasing rapidly, often to near 0 , after sunset. Rural areas downwind of urban pollution sources can experience a delay in this cycle, leading to more uniform daily $\mathrm{O}_{3}$ concentrations. This attenuation of the typical diurnal pattern results from additional time required to transport $\mathrm{O}_{3}$ and precursors from urban sources, along with continued $\mathrm{O}_{3}$ production during transport (USEPA, 2013).

In the residual layer of the atmosphere, which forms above a stable surface layer when vertical mixing is limited (Stull, 1988), $\mathrm{O}_{3}$ concentrations can also remain relatively constant throughout the day and night (Emberson et al., 2000; Forlani et al., 2005; Musselman and Minnick, 2000; Orendovici-Best et al., 2010; USEPA, 2013; Winner et al., 1989). Therefore, vegetation growing at higher elevations may be exposed to greater nighttime $\mathrm{O}_{3}$ levels. For example, at a mountainous site in rural central Pennsylvania, the mean $\mathrm{O}_{3}$ concentration from 9 June to 9 Sept. 2003 was 45 ppb (Orendovici, 2005, see Table 9). However, nighttime $\mathrm{O}_{3}$ levels often exceeded daytime concentrations, with maximum values around 100 ppb (Orendovici, 2005, see Fig. 9). Given the potential for nighttime $\mathrm{O}_{3}$ exposure, particularly in rural areas and high-elevation sites (Emberson et al., 2000; Forlani et al., 2005; Musselman and Minnick, 2000; USEPA, 2013), it is important to consider effects on plants.

To determine if nighttime $\mathrm{O}_{3}$ exposure causes injury and influences yield of $\mathrm{O}_{3}$-resistant ( $\mathrm{R} 123$ ) and $\mathrm{O}_{3}$-sensitive ( $\left.\mathrm{S} 156\right)$ snap bean genotypes (Burkey et al., 2005, 2012; Flowers et al., 2007; Reinert and Eason, 2000), the effects of day-only (0800$\left.1900 \mathrm{HR}=11 \mathrm{~h} \cdot \mathrm{d}^{-1}\right)$ and day + night $(0800-1900 \mathrm{HR}+2000$ $0700 \mathrm{HR}=22 \mathrm{~h} \cdot \mathrm{d}^{-1}$ ) exposure times at control $(3-15 \mathrm{ppb})$, low (25-49 ppb), and high concentrations (up to $78 \mathrm{ppb}$ ) were compared. Ozone treatments represented realistic nighttime levels based on observations from central Pennsylvania (Orendovici, 2005). The S156 and R123 genotypes were developed by the USDA-ARS Plant Science Research Unit in Raleigh, NC (Flowers et al., 2007; Reinert and Eason, 2000), and have been used to study flux-effect relationships by the International Cooperative Program on Effects of Air Pollution on Natural Vegetation and Crops (ICP Vegetation, 2012).

\section{Materials and Methods}

The experiments were conducted within a greenhouse on the University Park campus of The Pennsylvania State University (lat. $40.805640^{\circ} \mathrm{N}$, long. $77.852356^{\circ} \mathrm{W}$ ). Ozone treatments were administered in continuous stirred tank reactors [CSTR (Heck et al., 1978)]. The cylindrical CSTR chambers measured $1.5 \mathrm{~m}$ diameter by $1.5 \mathrm{~m}$ height and were enclosed with 76.2- $\mu \mathrm{m}$ transparent polytetrafluoroethylene (Teflon; Chemours, Wilmington, DE) film. Each chamber was equipped with an overhead 1000-W lamp having a spectral distribution of 350$700 \mathrm{~nm}$, with peaks at 550 and $650 \mathrm{~nm}$ (Lumalux; GTE Products Corp., Sylvania Lighting Center, Danvers, MA). Outside air was passed through activated charcoal filters to reduce $\mathrm{O}_{3}$ levels within the greenhouse. Mechanical blowers pulled the filtered greenhouse air into the CSTR chambers, with the full chamber volume exchanging about once per minute and exhaust released to the outside. $\mathrm{An}_{3}$ generator (Z-08; Ozone 
Solutions, Hull, IA) was used to produce $\mathrm{O}_{3}$ from dry air via electric current. Ozone was distributed to the CSTRs via manually adjusted valves and polytetrafluoroethylene tubing. Ozone levels in each chamber were monitored at 10-min intervals and adjusted using computerized feedback to the $\mathrm{O}_{3}$ generator. Air samples were collected at a rate of $\approx 1 \mathrm{~L} \cdot \mathrm{min}^{-1}$ using a network of computer-controlled solenoid valves and measured with two photometric ozone analyzers (model 49; Thermo Environmental Corp., Franklin, MA). Ozone measurements were recorded via custom data acquisition software (REAL Controls, Salix, PA). The software also tracked air temperature and relative humidity $(\mathrm{RH})$ data from sensors (HX93BC; Omega Engineering, Stamford, CT) installed in each chamber. Photosynthetically active radiation $(P A R)$ was recorded during the 2015 trials from four quantum sensors (LI190R; LI-COR, Lincoln, NE), which were positioned at canopy height in one chamber per experimental block.

Plant material. Seeds of the $\mathrm{O}_{3}$-resistant (R123) and $\mathrm{O}_{3}$ sensitive (S156) snap bean genotypes were provided by Dr. Kent Burkey of the USDA-ARS in Raleigh, NC. For the first two trials, Fall 2014 and Spring 2015, seeds were sown in 2.8-L pots. In the third trial, Fall 2015, 3.8-L pots were used. Pots were steam-sterilized at $82{ }^{\circ} \mathrm{C}$ for $20 \mathrm{~min}$. Each pot was filled with commercial potting media containing $63 \%$ to $73 \%$ peatmoss, perlite, and dolomitic limestone (Sunshine Mix \#4; Sun Gro Horticulture, Agawam, MA) that had been mixed with $15 \mathrm{~g}$ of $15 \mathrm{~N}-3.93 \mathrm{P}-9.96 \mathrm{~K}$ controlled-release fertilizer (Osmocote Plus; The Scotts Co., Marysville, $\mathrm{OH}$ ). Three bean seeds were planted in each pot under ambient greenhouse conditions. Planting dates for the three trials are given in Table 1 . When the first trifoliate leaves began to expand, plants were thinned to one per pot. Each seedling was tied to a 1-m bamboo stake for support.

Ozone Exposures. All three trials included four $\mathrm{O}_{3}$ treatments plus a control. The four $\mathrm{O}_{3}$ treatments were a combination of $\mathrm{O}_{3}$ concentration and treatment time as follows: 1) low $\mathrm{O}_{3}$, day-only, 2) high $\mathrm{O}_{3}$, day-only, 3) low $\mathrm{O}_{3}$, day + night, and 4) high $\mathrm{O}_{3}$, day + night (i.e., corresponding to day/night $\mathrm{O}_{3}$ levels of low/ambient, high/ambient, low/low, and high/high, respectively). The Fall 2014 trial included a fifth, night-only treatment time at low and high $\mathrm{O}_{3}$ concentrations (i.e., corresponding to day/night $\mathrm{O}_{3}$ levels of ambient/low and ambient/high, respectively). The day-only (0800-1900 HR) and night-only (2000$0700 \mathrm{HR}$ ) treatments were $\approx 11 \mathrm{~h}$ in duration, whereas the combined day + night treatments were $\approx 22 \mathrm{~h}$. Because the $\mathrm{O}_{3}$ supply to each chamber was fixed, plants in the day-only $\mathrm{O}_{3}$ treatments were rotated into a spare control chamber (one per block), subjected to greenhouse ambient conditions $+0 \mathrm{ppb}$ added $\mathrm{O}_{3}$, at night. For the night-only treatment in Fall 2014, plants were located in the spare control chamber during the day

Table 1. Seeding dates for snap bean with the number of days until flowering, harvest, and the start and end of $\mathrm{O}_{3}$ treatment for Fall 2014, Spring 2015, and Fall 2015 trials.

\begin{tabular}{lcccccc}
\hline & & \multicolumn{4}{c}{ Time after seeding $(\mathrm{d})$} & Total $_{3}$ \\
\cline { 2 - 6 } Trial & Seeding date & Start $\mathrm{O}_{3}$ & Flower & End $\mathrm{O}_{3}$ & Harvest & exposure $(\mathrm{d})^{\mathbf{z}}$ \\
\hline Fall 2014 & 16 Sept. & 15 & 29 & 38 & 92 & 18 \\
Spring 2015 & 28 Mar. & 26 & 33 & 45 & 102 & 14 \\
Fall 2015 & 4 Sept. & 28 & 34 & 53 & 79 & 21
\end{tabular}

${ }^{\bar{z}}$ Cumulative number of $\mathrm{O}_{3}$ treatment days; exposure times were $\approx 11 \mathrm{~h} \cdot \mathrm{d}^{-1}$ for the individual day and night treatments and $22 \mathrm{~h} \cdot \mathrm{d}^{-1}$ for the day + night treatments. and moved into their respective $\mathrm{O}_{3}$ treatment chamber at night. Randomized complete blocks of four chambers were calibrated by $\mathrm{O}_{3}$ level as follows: control (ambient $+0 \mathrm{ppb}$ ), spare (ambient $+0 \mathrm{ppb}$ ), low, and high. The Fall 2014 trial included two blocks, with target $\mathrm{O}_{3}$ concentrations of 30 and $60 \mathrm{ppb}$ for the low and high chambers, respectively. For each genotype, eight plants per $\mathrm{O}_{3}$ treatment and 14 plants for the control were divided between the two blocks. The Spring and Fall 2015 trials had four blocks, with target $\mathrm{O}_{3}$ concentrations of 45 and $75 \mathrm{ppb}$ for the low and high chambers, respectively. For each genotype, eight plants per treatment were divided between the four blocks.

Plants were acclimated to chamber conditions at least $48 \mathrm{~h}$ before $\mathrm{O}_{3}$ treatment. Ozone concentrations followed a squarewave pattern, reaching target levels within $15 \mathrm{~min}$ from the start of each fumigation period. On cloudy days, solar radiation was supplemented with the 1000-W lamps located above each chamber. Water was supplied as needed to maintain soil moisture near pot capacity, usually twice per day, between treatment times. Plants were randomized daily within their respective treatment chambers to minimize positional effects. On days when $\mathrm{O}_{3}$ treatments were not conducted, plants remained in the CSTR chambers with the doors open.

Ozone exposures commenced on 1 Oct. 2014 [15 d after seeding (DAS)], 23 Apr. 2015 (26 DAS), and 2 Oct. 2015 (28 DAS) for the three experiments. The number of exposure days ranged from 14 to 21 among trials (Table 1). At the conclusion of each trial, plants were removed from the CSTRs and randomized by block on greenhouse benches. Plants were grown under ambient light conditions and watered to pot capacity every 2-3 d until pods reached maturity. In Spring 2015 , initial signs of chlorosis were observed on 3 May $\{36$ DAS [10 d after treatment (DAT)]\}, and symptoms increased during the exposure period. During pod maturation, after plants had been removed from the CSTRs, most plants developed severe chlorosis as a result of nutrient deficiency from watering with high-calcium tap water. As a result, plants were watered with distilled water in Fall 2015.

Nocturnal STOMATAL CONDUCTANCE. A leaf porometer (SC1; Meter Group, Pullman, WA) was used to measure abaxial $g_{\text {sn }}$ during the time period from 2200 to $0100 \mathrm{HR}$. The terminal leaflet of a mature trifoliate leaf (i.e., leaf diameter ranging from 18 to $30 \mathrm{~cm}$ ) was used for measurements. Leaves with visible injury symptoms exceeding $20 \%$ of the leaf area were excluded from the analysis. At the time of $g_{\text {sn }}$ measurements, mature leaves of S156 were consistently smaller than R123 in the high $\mathrm{O}_{3}$ treatments. Conductance was measured following daytime $\mathrm{O}_{3}$ treatment on 30 Apr. and 7 May (33 and 40 DAS, respectively) in Spring 2015 and on 14 and 27 Oct. (40 and 53 DAS, respectively) during Fall 2015. Data reported for 14 Oct. 2015 represent the mean of two plants per replication. On the other three dates, one plant per replication was measured.

YiELD. Before harvesting, pods remained on the plants to dry. In a few cases, pods on S156 plants remained yellowish-green, whereas most of the R123 pods were brown. Any pod with one or more fully developed seeds was considered mature (sensu Burkey et al., 2005). 
For each plant, the number of mature pods was recorded. In Fall 2014 , each pod was opened and threshed by hand on 17 Dec., and the number of seeds per pod was counted. Seeds were dried at $21{ }^{\circ} \mathrm{C}$ for $24 \mathrm{~d}$ before weighing. In Spring and Fall 2015, pods harvested on 8 July and 23 Nov. were oven-dried at $66^{\circ} \mathrm{C}$ for $48 \mathrm{~h}$ and weighed.

Statistical anAlysis. The experimental design was a randomized complete block with four chambers per block and either two (Fall 2014) or four replications (Spring and Fall 2015). Chambers were the experimental units. The treatments followed an augmented factorial structure (Lentner and Bishop, 1993), with a factorial combination of two genotypes (i.e., $\mathrm{S} 156, \mathrm{R} 123$ ) and four day/night $\mathrm{O}_{3}$ combinations (i.e., low/ ambient, high/ambient, low/low, and high/high), along with a control (ambient/ambient). The Fall 2014 trial included two additional night-only $\mathrm{O}_{3}$ treatments (i.e., ambient/low and ambient/high).

Data from the three trials were analyzed separately. Response variables recorded in Fall 2014 were pod number, seed number, seed mass, seeds per pod, and mean seed mass (grams per seed). Pod number, pod mass, and $g_{\text {sn }}$ were recorded for Spring and Fall 2015. Values for multiple plants within an experimental unit were averaged before analysis. Block was considered a random effect. All data were subjected to analysis of variance in JMP Pro 12.1.0 (SAS Institute, Cary, NC) using the mixed model platform with restricted maximum likelihood methodology (REML) and Satterthwaite estimation for df. Single degree-of-freedom contrasts were used to test the significance of the main effects genotype, $\mathrm{O}_{3}$ level, and time (i.e., day vs. day + night), as well selected interactions (Marini, 2003). Differences were considered significant at $P \leq 0.05$.

\section{Results and Discussion}

Ozone Treatments. Table 2 provides a summary of mean $\mathrm{O}_{3}$ concentrations, separated into day and night exposure periods, for each of the three trials. Mean $\mathrm{O}_{3}$ levels in the control and spare chambers (greenhouse ambient +0 ppb added $\mathrm{O}_{3}$ ) ranged from 3 to $15 \mathrm{ppb}$ over the duration of the three experiments. In Fall 2014, target $\mathrm{O}_{3}$ concentrations for the low and high chambers were 30 and $60 \mathrm{ppb}$, respectively, and observed means were within 5 ppb (Table 2). In Spring and Fall 2015 , target $\mathrm{O}_{3}$ concentrations for the low and high treatments were 45 and $75 \mathrm{ppb}$, respectively. Mean $\mathrm{O}_{3}$ concentrations

Table 2. Mean, SD, and maximum (max) concentrations for ambient, low, and high $\mathrm{O}_{3}$ treatments, reported for day (0800-1900 HR) and night (2000-0700 HR) exposure times, over the duration of Fall 2014, Spring 2015, and Fall 2015 exposures.

\begin{tabular}{|c|c|c|c|c|c|c|c|c|c|c|}
\hline \multirow[b]{3}{*}{ Time } & & \multicolumn{9}{|c|}{$\mathrm{O}_{3}$ concn $(\mathrm{ppb})^{\mathrm{z}}$} \\
\hline & & \multicolumn{3}{|c|}{ Fall 2014} & \multicolumn{3}{|c|}{ Spring 2015} & \multicolumn{3}{|c|}{ Fall 2015} \\
\hline & & $\overline{A m b^{y}}$ & Low & High & $\overline{A m b^{y}}$ & Low & $\overline{\text { High }}$ & $\overline{\mathrm{Amb}^{\mathrm{y}}}$ & Low & High \\
\hline \multirow[t]{3}{*}{ Day } & $\bar{X}$ & 3 & 25 & 62 & 9 & 44 & 74 & 9 & 44 & 75 \\
\hline & $\mathrm{SD}$ & 2 & 4 & 8 & 3 & 5 & 11 & 5 & 9 & 9 \\
\hline & Max & 14 & 38 & 91 & 22 & 61 & 426 & 49 & 71 & 117 \\
\hline \multirow[t]{3}{*}{ Night } & $\bar{X}$ & 3 & 27 & 62 & 8 & 46 & 75 & 15 & 49 & 78 \\
\hline & SD & 3 & 4 & 9 & 4 & 4 & 6 & 5 & 6 & 8 \\
\hline & Max & 12 & 41 & 91 & 20 & 61 & 94 & 52 & 71 & 117 \\
\hline
\end{tabular}

${ }^{\mathrm{z}}$ Ozone levels represent the mean across chambers for each treatment.

${ }^{\mathrm{y}} \mathrm{Amb}=$ ambient (no added $\mathrm{O}_{3}$ ) includes means for the control and spare chambers. observed in the low and high chambers for Spring and Fall 2015 were within 1 and $4 \mathrm{ppb}$ of target levels, respectively.

Because $\mathrm{O}_{3}$ was generated via an electric current using dry air, instead of pure $\mathrm{O}_{2}$, small amounts of $\mathrm{N}_{2} \mathrm{O}_{5}$ and $\mathrm{N}_{2} \mathrm{O}$ were also likely produced (Harris et al., 1982). Using electric discharge, production of $\mathrm{N}_{2} \mathrm{O}_{5}$ from dry air has been estimated at $0.02-0.025 \mathrm{mmol} \mathrm{N}_{2} \mathrm{O}_{5}$ per $\mathrm{mmol} \mathrm{O}_{3}$ (Brown and Roberts, 1988; Mortensen and Jørgensen, 1996). However, in open-top chambers, actual levels of $\mathrm{HNO}_{3}$, the hydrated form of $\mathrm{N}_{2} \mathrm{O}_{5}$, were lower in the added $\mathrm{O}_{3}$ treatment than ambient air (Bytnerowicz et al., 1995). Although pure $\mathrm{O}_{2}$ is the ideal source gas for high-voltage $\mathrm{O}_{3}$ generation, cost and maintenance issues are prohibitive for long-term studies (Mortensen and Jørgensen, 1996; Olszyk et al., 1990). Given the low $\mathrm{O}_{3}$ concentrations in this study, it is unlikely that incidental production of other trace oxidants impacted results.

Greenhouse ENVIRONMENT. Mean daytime air temperatures in the CSTRs ranged from 24 to $25{ }^{\circ} \mathrm{C}$ during the three trials, with nighttime means in the range of 20 to $22^{\circ} \mathrm{C}$ (Table 3 ). Maximum daytime air temperatures did not exceed $37^{\circ} \mathrm{C}$, and a minimum temperature of $12{ }^{\circ} \mathrm{C}$ occurred once in Fall 2015. Mean RH in the CSTRs ranged from $49 \%$ to $57 \%$ during the day and $46 \%$ to $56 \%$ at night for the three trials (Table 3 ). RH values near $50 \%$ represent realistic conditions for $\mathrm{O}_{3}$ exposure, given that $\mathrm{O}_{3}$ production is generally greatest during hot, dry weather conditions associated with stagnant high pressure systems (Ryan et al., 2000; USEPA, 2013).

Phenology and onset of injury. In Fall 2014, $\mathrm{O}_{3}$ treatments began at 15 DAS, before full expansion of the second trifoliate leaf (19 DAS for all plants). Plants bloomed by 29 DAS and began pod fill at 35 DAS. At 37 DAS, the second to last day of $\mathrm{O}_{3}$ treatment, the largest pod was $\approx 5 \mathrm{~cm}$ in length. Plants grew more slowly in Spring 2015, with the second trifoliate leaf expanded at 24 DAS. Ozone treatments also began later, at $26 \mathrm{DAS}$, and all plants flowered by $33 \mathrm{DAS}$. The largest pods reached $\approx 5 \mathrm{~cm}$ at 37 DAS. In Fall 2015, plants had at least three to four expanded leaves when $\mathrm{O}_{3}$ exposures began at 28 DAS. All plants flowered by 34 DAS, and pods were $12-$ $15 \mathrm{~cm}$ in length at 44 DAS.

No injury was observed for the night-only $\mathrm{O}_{3}$ treatments in Fall 2014. By contrast, daytime $\mathrm{O}_{3}$ exposure produced stippling, bleaching, and mesophyll collapse on foliage of both genotypes, with curling on the leaf margins of S156 exposed to high $\mathrm{O}_{3}$ levels. In Fall 2014, foliar injury symptoms appeared 5 DAT in the high $\mathrm{O}_{3}$ treatments. Injury progressed in both genotypes with cumulative exposure to high $\mathrm{O}_{3}$, but no symptoms were apparent at low $\mathrm{O}_{3}($ mean $=25$ $\mathrm{ppb}$ ). At the conclusion of the trial, S156 plants exposed to $62 \mathrm{ppb}$ mean $\mathrm{O}_{3}$ during the day appeared stunted, with smaller leaves relative to R123 plants, and developed greater foliar injury. Injury symptoms appeared on plants treated with high $\mathrm{O}_{3}$ (mean $=74 \mathrm{ppb}$ ) on 2 DAT in Spring 2015. At 3 DAT, stippling was also evident on plants in the 45-ppb treatments. By 17 DAT, early leaf abscission occurred in the 75-ppb treatments. In Fall 2015, $\mathrm{O}_{3}$ injury appeared in the high and low $\mathrm{O}_{3}$ 
treatments 1 and 5 DAT, respectively. At 16 DAT, premature leaf abscission occurred on plants of both genotypes exposed to $75 \mathrm{ppb} \mathrm{O}_{3}$. Across the three trials, mean daytime $\mathrm{O}_{3}$ exposures greater than $45 \mathrm{ppb}$ caused foliar injury to both genotypes. However, only the high $\mathrm{O}_{3}$ treatment (mean daytime $\mathrm{O}_{3} \geq 60$ $\mathrm{ppb}$ ) caused early leaf abscission.

Table 3. Mean, SD, minimum ( $\min$ ), and maximum ( $\max$ ) values across all treatment chambers for air temperature, relative humidity $(\mathrm{RH})$, and photosynthetically active radiation $(P A R)$, reported for day (0800-1900 HR) and night (2000-0700 HR) exposure times, over the duration of Fall 2014, Spring 2015, and Fall 2015 exposure periods.

\begin{tabular}{|c|c|c|c|c|c|c|c|c|c|}
\hline & \multicolumn{3}{|c|}{ Air temp $\left({ }^{\circ} \mathrm{C}\right)$} & \multicolumn{3}{|c|}{ RH (\%) } & \multicolumn{2}{|c|}{$P A R\left(\mu \mathrm{mol} \cdot \mathrm{m}^{-2} \cdot \mathrm{s}^{-1}\right)^{\mathrm{z}}$} \\
\hline & & Fall 14 & Spring 15 & Fall 15 & Fall 14 & Spring 15 & Fall 15 & Spring 15 & Fall 15 \\
\hline \multirow[t]{4}{*}{ Day } & $\bar{X}$ & 24 & 25 & 24 & 57 & 49 & 49 & 507 & 537 \\
\hline & $\mathrm{SD}$ & 3 & 4 & 3 & 10 & 15 & 8 & 408 & 303 \\
\hline & Min & 19 & 14 & 12 & 32 & 16 & 24 & 7 & 1 \\
\hline & Max & 37 & 36 & 36 & 81 & 84 & 79 & 2,313 & 1,763 \\
\hline \multirow[t]{4}{*}{ Night } & $\bar{X}$ & 21 & 22 & 20 & 56 & 46 & 53 & 7 & 1 \\
\hline & $\mathrm{SD}$ & 1 & 2 & 1 & 11 & 16 & 8 & 23 & 3 \\
\hline & Min & 18 & 17 & 15 & 34 & 17 & 35 & 0 & 0 \\
\hline & Max & 22 & 26 & 24 & 90 & 83 & 77 & 300 & 71 \\
\hline
\end{tabular}

${ }^{\mathrm{z}} P A R$ values were recorded from one chamber per block $(n=4)$ in Spring and Fall 2015.
Fall 2014: Yield. Given the absence of visual injury in the Fall 2014 night-only (2000-0700 HR) $\mathrm{O}_{3}$ exposures, it was not surprising that night $\mathrm{O}_{3}$ treatment (high $\mathrm{O}_{3}$ mean $=62 \mathrm{ppb}$ ) did not significantly affect any yield parameter (Table 4). Among the control and night-only $\mathrm{O}_{3}$ treatments, seed mass for R123 and S156 varied by only $1.6 \%$ and $5.7 \%$, respectively. Other studies have also failed to demonstrate significant injury from nightonly $\mathrm{O}_{3}$ exposure. Günthardt-Goerg (1996) found that night-only $\mathrm{O}_{3}$ treatment at $75 \mathrm{ppb}$ did not produce foliar injury on a sensitive tobacco (Nicotiana tabacum L.) cultivar (BelW3). For turnip plants grown in open-top chambers, there was no significant difference in total plant biomass for plants exposed to ambient $\mathrm{O}_{3}$ during either the day or night in three separate trials (Winner et al., 1989, see Table 1 therein). Using Plexiglas chambers, Goknur and Tibbitts (2001) found that a dark period $\mathrm{O}_{3}$ concentration of $\approx 300 \mathrm{ppb}$

Table 4. Yield parameters of $\mathrm{O}_{3}$ resistant (R123) and $\mathrm{O}_{3}$ sensitive (S156) snap bean genotypes and single degree-of-freedom contrasts comparing the effects of day (0800-1900 HR) and night (2000-0700 HR) $\mathrm{O}_{3}$ treatment combinations in Fall $2014(n=2)$.

\begin{tabular}{|c|c|c|c|c|c|c|c|c|}
\hline \multirow[b]{2}{*}{ Treatment } & \multirow[b]{2}{*}{ Genotype } & \multicolumn{2}{|c|}{ Ozone $^{z}$} & \multirow{2}{*}{$\frac{\text { Pods }}{\text { (no.) }}$} & \multicolumn{2}{|c|}{ Seeds } & \multicolumn{2}{|c|}{ Seed mass } \\
\hline & & Day & Night & & (no.) & (no./pod) & (g) & $(\mathrm{g} / \mathrm{seed})$ \\
\hline 1 (Control) & R123 & AMB & AMB & 12.9 & 57.9 & 4.55 & 16.32 & 0.290 \\
\hline 2 & R123 & LOW & AMB & 11.5 & 55.5 & 4.82 & 16.45 & 0.301 \\
\hline 4 & R123 & LOW & LOW & 13.9 & 62.0 & 4.46 & 17.33 & 0.289 \\
\hline 5 & R123 & HIGH & AMB & 11.4 & 51.3 & 4.51 & 15.00 & 0.303 \\
\hline 8 (Control) & S156 & AMB & AMB & 17.1 & 59.2 & 3.52 & 16.77 & 0.295 \\
\hline 9 & S156 & LOW & AMB & 17.3 & 60.5 & 3.52 & 17.93 & 0.313 \\
\hline 10 & S156 & AMB & LOW & 15.8 & 56.3 & 3.58 & 17.03 & 0.314 \\
\hline 11 & S156 & LOW & LOW & 16.3 & 60.4 & 3.74 & 16.91 & 0.290 \\
\hline 12 & S156 & HIGH & AMB & 8.4 & 22.9 & 2.75 & 7.28 & 0.346 \\
\hline 13 & S156 & AMB & HIGH & 16.9 & 61.5 & 3.66 & 17.78 & 0.305 \\
\hline C vs. L & $+10)$ & & & 0.430 & 0.614 & 0.799 & 0.842 & 0.713 \\
\hline $\mathrm{C}$ vs. $\mathrm{H}($ & + 13) & & & 0.973 & 0.513 & 0.223 & 0.578 & 0.943 \\
\hline L vs. H & $5+13)$ & & & 0.411 & 0.256 & 0.326 & 0.719 & 0.661 \\
\hline \multicolumn{9}{|c|}{ Day $\mathrm{O}_{3}$ treatments $^{\mathrm{x}}$} \\
\hline Gn $(2+4$ & $9+11+1$ & & & 0.769 & 0.001 & 0.001 & 0.001 & 0.572 \\
\hline C vs. L ( & $+4+9+1$ & & & 0.787 & 0.779 & 0.346 & 0.536 & 0.880 \\
\hline C vs. H ( & $+7+12+$ & & & 0.001 & 0.001 & 0.002 & 0.001 & 0.682 \\
\hline L vs. H & 11 vs. $5+$ & 14) & & 0.001 & 0.001 & 0.001 & 0.001 & 0.750 \\
\hline Time $(2+5$ & s. $4+7+1$ & & & 0.769 & 0.693 & 0.728 & 0.588 & 0.429 \\
\hline \multicolumn{9}{|c|}{ Interaction } \\
\hline $\mathrm{O}_{3} \times \mathrm{Gn}$ & +11 vs. $2+$ & $-14)^{\mathrm{w}}$ & & 0.001 & 0.001 & 0.004 & 0.001 & 0.728 \\
\hline
\end{tabular}

${ }^{\mathrm{z}}$ Mean $\mathrm{O}_{3}$ levels were AMB (no added $\mathrm{O}_{3}$ ) $=3$ ppb day and night; LOW = 25 ppb day, 27 ppb night; HIGH $=62$ ppb day and night.

${ }^{\mathrm{y}}$ Each contrast compares individual treatments or combinations of treatments as noted by treatment numbers. $\mathrm{C}=\mathrm{control} ; \mathrm{L}=1$ low $\mathrm{O}_{3}$; $\mathrm{H}=$ high $\mathrm{O}_{3} ; \mathrm{Gn}=$ genotype; Time = day vs. day + night.

${ }^{\mathrm{x}}$ Low and high $\mathrm{O}_{3}$ levels are pooled across day and day + night treatment times.

${ }^{\mathrm{w}}$ Compares response of genotypes to low and high $\mathrm{O}_{3}$, pooled across day and day + night treatment times. 
$\mathrm{O}_{3}$ was required to induce similar foliar injury to potato as exposure to $100 \mathrm{ppb}$ in the light, over 3-h time periods (see Fig. 5 therein).

Under control conditions, S156 produced significantly more mature pods than R123 in Fall $2014[P=0.031$ (Table 4)]. However, R123 had significantly more seeds per pod than S156 $(P<0.001)$, with means of 4.55 and 3.52 , respectively. Therefore, although S156 tended to produce more pods than R123, R123 had a greater number of seeds in each pod, leading to similar yields by mass $(\mathrm{S} 156: \mathrm{R} 123=1.03)$. Total seed number and mean seed mass (grams per seed) were not significantly different for the two genotypes. Similarly, Burkey et al. (2005) observed greater pod numbers with fewer seeds per pod in S156 than R123, leading to similar yields by mass, when plants were grown in open-top chambers with charcoal-filtered air. Therefore, mass-based yield can be compared more directly than pod number for the two genotypes.

High $\mathrm{O}_{3}$ treatment during the day (mean $\left.=62 \mathrm{ppb}\right)$ significantly reduced all yield parameters $(P<0.001)$, except mean seed mass, relative to both the control and low $\mathrm{O}_{3}($ mean $=$ $25 \mathrm{ppb}$ ) treatments (Table 4). However, yields under low $\mathrm{O}_{3}$ were not significantly different from the control. Flowers et al. (2007) also found that both R123 and S156 tolerated $\mathrm{O}_{3}$ concentrations less than $30 \mathrm{ppb}$. Notably, the interaction of genotype and $\mathrm{O}_{3}$ (low vs. high) was significant for all yield parameters except mean seed mass. Pooled across the day and day + night timings, the increase in mean daytime $\mathrm{O}_{3}$ from 25 to $62 \mathrm{ppb}$ decreased total seed mass by $39 \%$ for S156 but only 9\% for R123. Similarly, total seed number declined by $63 \%$ (S156) and $13 \%$ (R123), with decreases of $22 \%$ (S156) and 4.5\% (R123) in the number of seeds per pod (Table 4). Therefore, exposure to $62 \mathrm{ppb} \mathrm{O}_{3}$ had a greater impact on both pod initiation and maturation in S156 than $\mathrm{R} 123$. Mass yield ratios (S156:R123) for the low and high $\mathrm{O}_{3}$ treatments were 1.03 and 0.47 , respectively, compared with 1.03 for the control.

SPRING ANd Fall 2015: Yield. In contrast to Fall 2014 (Table 4) and Spring 2015, R123 produced significantly greater pod mass than S156 under control conditions in Fall $2015[P<0.001$ (Table 5)]. In Fall 2015, plants were relatively larger when transferred into the CSTRs, with three to four expanded trifoliate leaves. In addition, higher PAR levels and lower air temperature likely enhanced growth in Fall 2015 compared with Spring 2015 (Table 3). Ratios of S156:R123 pod mass in the controls for Spring and Fall 2015 were 0.91 and 0.77 , respectively. For plants grown outdoors in charcoal-filtered air, over 78 (fall) ppb night. times. two subsequent years (seasonal mean $\mathrm{O}_{3}=25-31 \mathrm{ppb}$ ), the S156:R123 yield ratio was about 1.0 (Burkey et al., 2005). Similarly, Flowers et al. (2007) noted a seed yield ratio of $\approx 1$ for S156 and R123 plants grown in environmentally controlled field chambers (mean $\mathrm{O}_{3}=0 \mathrm{ppb}$ ). However, plants grown in the same facility, exposed to $0 \mathrm{ppb}_{3}$ in combination with low and high vapor pressure deficit treatments, had seed mass ratios of about 0.72 and 0.70 , respectively (Fiscus et al., 2012). Agathokleous et al. (2017) showed that small increases in air temperature, particularly in the range of 31 to $34^{\circ} \mathrm{C}$, can substantially decrease pod number and affect the mass of pods and seeds for S156 and R123. Therefore, S156:R123 yield ratios may vary with environmental factors (e.g., temperature, RH, $P A R$, nutrient availability) and cultural practices (e.g., container volume, media composition) and should be interpreted with caution (Burkey et al., 2012).

Data for the day and day + night treatments were pooled to compare the effects of the low and high $\mathrm{O}_{3}$ treatments relative to the control and each other. Across genotypes, the low $\mathrm{O}_{3}$ treatments $($ mean $=44 \mathrm{ppb})$ significantly decreased pod number $(P<0.001)$ and mass $(P<0.001)$ in Fall 2015 only (Table 5). In Fall 2015, plants were 2-d older at the beginning of treatments, and the exposures lasted 7-d longer than in Spring (Table 1). High $\mathrm{O}_{3}$ (mean $=74$ and 75 ppb for Spring 2015 and Fall 2015, respectively) significantly reduced pod number and mass

Table 5. Yield parameters of $\mathrm{O}_{3}$ resistant (R123) and $\mathrm{O}_{3}$ sensitive (S156) snap bean genotypes and single degree-of-freedom contrasts comparing the effects of day (0800-1900 HR) and day + night $(0800-1900 \mathrm{HR}+2000-0700 \mathrm{HR}) \mathrm{O}_{3}$ treatments in Spring 2015 and Fall $2015(n=4)$.

\begin{tabular}{|c|c|c|c|c|c|c|c|}
\hline \multirow[b]{2}{*}{ Treatment } & \multirow[b]{2}{*}{ Genotype } & \multicolumn{2}{|c|}{ Ozone $^{z}$} & \multicolumn{2}{|c|}{ Pod no. } & \multicolumn{2}{|c|}{ Pod mass (g) } \\
\hline & & Day & Night & Spring & Fall & Spring & Fall \\
\hline 1 (Control) & R123 & AMB & AMB & 22.5 & 24.9 & 31.47 & 37.16 \\
\hline 2 & $\mathrm{R} 123$ & LOW & AMB & 21.4 & 20.9 & 28.01 & 31.14 \\
\hline 3 & R123 & LOW & LOW & 22.3 & 21.0 & 30.03 & 32.13 \\
\hline 4 & R123 & $\mathrm{HIGH}$ & AMB & 19.3 & 16.9 & 27.26 & 21.23 \\
\hline 5 & R123 & $\mathrm{HIGH}$ & HIGH & 18.6 & 17.1 & 24.55 & 21.44 \\
\hline 6 (Control) & S156 & AMB & AMB & 28.1 & 26.8 & 28.62 & 28.73 \\
\hline 7 & S156 & LOW & AMB & 26.6 & 22.5 & 29.28 & 23.54 \\
\hline 8 & S156 & LOW & LOW & 24.9 & 21.0 & 27.01 & 22.95 \\
\hline 9 & S156 & HIGH & AMB & 18.9 & 14.5 & 19.51 & 13.45 \\
\hline 10 & S156 & $\mathrm{HIGH}$ & HIGH & 18.9 & 14.8 & 18.19 & 11.75 \\
\hline \multicolumn{8}{|c|}{ Contrast $(P>F)^{\mathrm{y}}$} \\
\hline Control: & vs. 6) & & & 0.004 & 0.197 & 0.265 & 0.001 \\
\hline \multicolumn{8}{|c|}{$\mathrm{O}_{3}$ treatments $^{\mathrm{x}}$} \\
\hline Gn $(2+3$ & 5 vs. $7+8$ & $+10)$ & & 0.041 & 0.280 & 0.004 & 0.001 \\
\hline C vs. L ( & s. $2+3+7$ & & & 0.177 & 0.001 & 0.347 & 0.001 \\
\hline $\mathrm{C}$ vs. $\mathrm{H}($ & s. $4+5+9$ & & & 0.001 & 0.001 & 0.001 & 0.001 \\
\hline L vs. H & $-7+8$ vs. 4 & $+9+10)$ & & 0.001 & 0.001 & 0.001 & 0.001 \\
\hline Time $(2+4$ & 9 vs. $3+5-$ & 10) & & 0.681 & 0.760 & 0.400 & 0.740 \\
\hline \multicolumn{8}{|c|}{ Interactions } \\
\hline $\mathrm{O}_{3} \times \mathrm{Gn}$ & $+7+8$ vs. & $+9+10)^{\mathrm{w}}$ & & 0.035 & 0.033 & 0.020 & 0.833 \\
\hline Time $\times \mathrm{G}$ & $2+8$ vs. $3+$ & & & 0.312 & 0.425 & 0.237 & 0.500 \\
\hline Time $\times C$ & $4+10$ vs. 5 & & & 0.808 & 1.000 & 0.696 & 0.416 \\
\hline
\end{tabular}

${ }^{\mathrm{z}}$ Mean $\mathrm{O}_{3}$ levels were AMB (no added $\mathrm{O}_{3}$ ) $=9$ ppb day, 8 (spring) and 15 (fall) ppb night; LOW $=44$ ppb day, 46 (spring) and 49 (fall) ppb night; HIGH = 74 (spring) and 75 (fall) ppb day, 75 (spring) and

${ }^{\mathrm{y}}$ Each contrast compares individual treatments or combinations of treatments as noted by treatment numbers. $\mathrm{C}=$ control; $\mathrm{L}=$ low $\mathrm{O}_{3} ; \mathrm{H}=$ high $\mathrm{O}_{3} ; \mathrm{Gn}=$ genotype; Time $=$ day vs. day + night.

${ }^{x}$ Low and high $\mathrm{O}_{3}$ levels are pooled across day and day + night treatment times.

${ }^{\mathrm{w}}$ Compares response of genotypes to low and high $\mathrm{O}_{3}$, pooled across day and day + night treatment 
relative to both the control and low $\mathrm{O}_{3}$ treatments [all $P<0.001$ (Table 5)]. However, the interaction of genotype and $\mathrm{O}_{3}$ (low vs. high) had a significant effect on pod number in Spring $(P=$ $0.035)$ and Fall $2015(P=0.033)$. The decreases in pod number at high $\mathrm{O}_{3}$ during Spring and Fall were greater for S156 (27\% and $33 \%$, respectively) than $\mathrm{R} 123(13 \%$ and $11 \%$, respectively). For pod mass, the interaction was significant in Spring $(P=0.020)$ but not Fall 2015. In Spring 2015, R123 pod mass was $11 \%$ lower under high $\mathrm{O}_{3}$ than low $\mathrm{O}_{3}$, whereas $\mathrm{S} 156$ pod mass was 33\% less. By contrast, R123 pod mass decreased by $33 \%$ in Fall 2015, with a $46 \%$ reduction for S156. Therefore, the high $\mathrm{O}_{3}$ treatment had greater effects on yield in Fall 2015, when exposures were 7-d longer in duration (Table 1). Flowers et al. (2007) also observed a significant decrease in the seed yield, by mass, of both genotypes at $60 \mathrm{ppb} \mathrm{O}_{3}$. Compared with the control, they reported $19 \%$ and $77 \%$ reductions for $\mathrm{R} 123$ and $\mathrm{S} 156$, respectively. In contrast to the present study, $\mathrm{O}_{3}$ treatments began 1 week after planting, starting at one-third of the target $\mathrm{O}_{3}$ level and increasing in two steps during the second week of treatment. Their approach provided more time for the plants to acclimate to $\mathrm{O}_{3}$ stress, as well as the opportunity to respond at a younger age than in the present study, which appeared to minimize R123 yield losses relative to S156. Fiscus et al. (2012), using environmentally controlled field chambers, noted $\approx 55 \%$ and $72 \%$ reductions in seed yield for R123 and $\mathrm{S} 156$, respectively, at low vapor-pressure deficit $(1.26 \mathrm{kPa})$ and $60 \mathrm{ppb} \mathrm{O}_{3}$. Using open-top field chambers, Heagle et al. (2002) observed a striking decline of $90 \%$ pod mass for S156 when exposed to $73 \mathrm{ppb}$ relative to $23 \mathrm{ppb}$, but the study did not include R123.

In contrast to the present results, mature pod $(>4 \mathrm{~cm}$ with seeds) mass decreases of only $28 \%$ and $30 \%$ for R 123 and S156, respectively, were reported for plants exposed to a mean of 78 ppb $\mathrm{O}_{3}$ for $20 \mathrm{~d}$ in enclosed chambers (Salvatori et al., 2013). The relatively minor impact of $\mathrm{O}_{3}$ on yield was accompanied by overall low yields. For example, the researchers reported 13.8 and 19.2 pods per plant for R123 and S156, respectively, under control conditions. In comparison, the number of pods per plant for R123 and S156 in the present study ranged from 12.9 to 24.9 and 17.1 to 28.1 , respectively (Tables 4 and 5). The minimum values were recorded in Fall 2014, when twice as many plants were grown in each CSTR, leading to space constraints and competition for light that likely reduced yields. In the study by Salvatori et al. (2013), plants were potted in a combination of field soil and sand, which may have inhibited aeration and drainage. In addition, light was provided entirely by metal halide lamps, resulting in low $P A R$ levels at leaf height (i.e., 350 $\left.\mu \mathrm{mol} \cdot \mathrm{m}^{-2} \cdot \mathrm{s}^{-1}\right)$. Exposure to high light levels $\left(>1000 \mu \mathrm{mol} \cdot \mathrm{m}^{-2} \cdot \mathrm{s}^{-1}\right)$ can increase the negative impacts of $\mathrm{O}_{3}$ on photosynthesis (Guidi et al., 2000). Therefore, suboptimal growth conditions may have confounded the effects of $\mathrm{O}_{3}$ treatment observed by Salvatori et al. (2013).

Daytime $\mathrm{O}_{3}$ treatment (mean $=44-75 \mathrm{ppb}$ ) resulted in significantly lower pod mass for S156 relative to R123 in both Spring and Fall 2015 (Table 5). Pooled across treatment times, pod mass yield ratios of S156:R123 at low $\mathrm{O}_{3}$ were 0.97 and 0.73 in Spring and Fall 2015, respectively. At high $\mathrm{O}_{3}$, those ratios declined to 0.73 (Spring) and 0.59 (Fall).

Similar to Fall 2014, the timing of $\mathrm{O}_{3}$ exposure (i.e., day vs. day + night) did not significantly affect yield responses in Spring or Fall 2015 (Table 5). For tobacco, there was no difference in the onset of foliar symptoms between day-only and continuous (i.e., day + night) $\mathrm{O}_{3}$ exposures, but biomass was not reported (Günthardt-Goerg, 1996). Winner et al. (1989) obtained inconsistent results for turnip grown in open-top chambers in which charcoal filters were used to reduce ambient $\mathrm{O}_{3}$ from between 50 and $100 \mathrm{ppb}$ to $\leq 25 \mathrm{ppb}$. Plants exposed continuously to ambient $\mathrm{O}_{3}$ had significantly lower biomass than plants exposed during the day only (i.e., charcoal-filtered air at night) in one of three trials, whereas treatments were not significantly different in the other two trials. Therefore, more evidence is required to support the hypothesis that nighttime $\mathrm{O}_{3}$ exposure, at realistic concentrations, exacerbates daytime $\mathrm{O}_{3}$ injury.

Nocturnal stomatal Conductance. Nighttime conductance measurements in Spring and Fall 2015 showed significant differences between genotypes in the control (ambient $+0 \mathrm{ppb}$ ) on two of four observation dates (Table 6). On each date, S156 maintained higher $g_{\mathrm{sn}}$, ranging from 73.8 to $94.1 \mathrm{mmol} \cdot \mathrm{m}^{-2} \cdot \mathrm{s}^{-1}$, relative to $\mathrm{R} 123$, with $g_{\mathrm{sn}}$ in the range of 48.0 to 61.9 $\mathrm{mmol} \cdot \mathrm{m}^{-2} \cdot \mathrm{s}^{-1}$. These results support the observation that $\mathrm{S} 156$ has higher $g_{\text {sn }}$ relative to R123 (Salvatori et al., 2013), potentially leading to higher nighttime $\mathrm{O}_{3}$ fluxes per unit leaf area. However, compared with the present study, Salvatori et al. (2013) reported lower $g_{\text {sn }}$ values for both genotypes under control conditions (mean $\mathrm{O}_{3}=4 \mathrm{ppb}$ ) when measured from 39 to $42 \mathrm{DAS}$, with means of 28 and $12 \mathrm{mmol} \cdot \mathrm{m}^{-2} \cdot \mathrm{s}^{-1}$ for S156 and $\mathrm{R} 123$, respectively. In the current experiment, plants were watered 2-3 h before measurement, which likely resulted in maximal $g_{\mathrm{sn}}$. In addition, daytime $P A R$ values were higher, with means of 507-537 $\mu \mathrm{mol} \cdot \mathrm{m}^{-2} \cdot \mathrm{s}^{-1}$ in (Table 3 ), compared with the artificial lighting used by Salvatori et al. (2013), which supplied a constant $350 \mu \mathrm{mol} \cdot \mathrm{m}^{-2} \cdot \mathrm{s}^{-1}$. Greater light availability in the CSTRs likely supported higher rates of photosynthesis and transpiration, as well as increased $g_{\mathrm{sn}}$, relative to enclosed growth chambers (Easlon and Richards, 2009).

At elevated $\mathrm{O}_{3}, g_{\text {sn }}$ varied significantly between genotypes on all four dates, with higher $g_{\text {sn }}$ for $\mathrm{S} 156$ in each $\mathrm{O}_{3}$ treatment (Table 6). Rates of $g_{\text {sn }}$ for S156 ranged from 66.0 to 185.5 $\mathrm{mmol} \cdot \mathrm{m}^{-2} \cdot \mathrm{s}^{-1}$, and values for R123 were between 33.8 and 69.7 $\mathrm{mmol} \cdot \mathrm{m}^{-2} \cdot \mathrm{s}^{-1}$. Salvatori et al. (2013) reported $g_{\mathrm{sn}}$ for $\mathrm{O}_{3}$-treated $\mathrm{S} 156$ and R123 plants of $\approx 88$ and $44 \mathrm{mmol} \cdot \mathrm{m}^{-2} \cdot \mathrm{s}^{-1}$, respectively, in agreement with the present study.

Across genotypes and exposure times, $\mathrm{O}_{3}$ had a significant effect on $g_{\text {sn }}$ only on 27 Oct. (Table 6). There was no difference between the control and low $\mathrm{O}_{3}$ treatment, but $g_{\text {sn }}$ rates in the high $\mathrm{O}_{3}$ treatment were significantly greater than values from the control $(P=0.009)$ and low $\mathrm{O}_{3}$ treatment $(P<0.001)$. The interaction of $\mathrm{O}_{3}$ (low vs. high) and genotype was also significant on 27 Oct. $(P=0.002)$, with a much greater increase in $g_{\mathrm{sn}}$ for $\mathrm{S} 156(90 \%)$ in the high treatments than R123 (29\%). In addition, the interaction was significant between the control and high $\mathrm{O}_{3}$ treatment on 14 Oct. $(P=0.032)$ because of a decrease $(-23 \%)$ in $g_{\text {sn }}$ for R123 and increase for S156 (7\%) with elevated $\mathrm{O}_{3}$. The effects of $\mathrm{O}_{3}$ treatment may have been more advanced on 27 Oct. (25 DAT) relative to the three earlier sampling times (7-14 DAT), leading to greater $g_{\text {sn }}$ at high $\mathrm{O}_{3}$ in both genotypes.

Similarly, Salvatori et al. (2013) reported that exposure to 75 ppb $\mathrm{O}_{3}\left(7 \mathrm{~h} \cdot \mathrm{d}^{-1}\right.$ for $\left.20 \mathrm{~d}\right)$ caused a significant increase in $g_{\mathrm{sn}}$ and dark respiration $\left(R_{\mathrm{d}}\right)$ compared with control conditions, when measured from 17 to $20 \mathrm{DAT}$, for both genotypes. However, the relative increases were greater for $\mathrm{R} 123\left(g_{\mathrm{sn}}=271 \%\right.$ and $R_{\mathrm{d}}=$ $29 \%)$ than $\mathrm{S} 156\left(g_{\mathrm{sn}}=209 \%, R_{\mathrm{d}}=9 \%\right)$. They hypothesized that 
Table 6. Nocturnal stomatal conductance $\left(g_{\mathrm{sn}}\right)$ for $\mathrm{O}_{3}$ resistant $(\mathrm{R} 123)$ and $\mathrm{O}_{3}$ sensitive (S156) snap bean genotypes and single degree-of-freedom contrasts comparing the effects of day (0800-1900 $\mathrm{HR})$ and day + night (0800-1900 HR + 2000-0700 HR) $\mathrm{O}_{3}$ treatments for Spring (April, May) and Fall 2015 (October) trials $(n=4)$.

\begin{tabular}{|c|c|c|c|c|c|c|c|}
\hline \multirow{2}{*}{ Treatment } & \multirow[b]{2}{*}{ Genotype } & \multicolumn{2}{|c|}{ Ozone $^{z}$} & \multicolumn{4}{|c|}{$g_{\mathrm{sn}}\left(\mathrm{mmol} \cdot \mathrm{m}^{-2} \cdot \mathrm{s}^{-1}\right)$} \\
\hline & & Day & Night & $30 \mathrm{Apr}$. & 7 May & 14 Oct. $^{y}$ & 27 Oct. \\
\hline 1 (Control) & R123 & AMB & AMB & 57.0 & 61.9 & 54.4 & 48.0 \\
\hline 2 & $\mathrm{R} 123$ & LOW & AMB & 42.8 & 56.6 & - & 33.8 \\
\hline 3 & R123 & LOW & LOW & 69.7 & 65.5 & - & 38.5 \\
\hline 4 & R123 & HIGH & AMB & 62.0 & 56.9 & 39.0 & 50.1 \\
\hline 5 & R123 & HIGH & $\mathrm{HIGH}$ & 55.7 & 46.2 & 45.2 & 43.1 \\
\hline 6 (Control) & S156 & AMB & AMB & 94.1 & 73.8 & 88.3 & 88.9 \\
\hline 7 & S156 & LOW & AMB & 72.2 & 95.8 & - & 89.2 \\
\hline 8 & $\mathrm{~S} 156$ & LOW & LOW & 73.6 & 66.0 & 一 & 67.5 \\
\hline 9 & S156 & HIGH & $\mathrm{AMB}$ & 71.4 & 67.9 & 107.0 & 185.5 \\
\hline 10 & S156 & HIGH & $\mathrm{HIGH}$ & 73.6 & 129.8 & 81.5 & 112.5 \\
\hline \multicolumn{8}{|c|}{ Contrast $(P>\mathrm{F})^{\mathrm{x}}$} \\
\hline Control: & vs. 6) & & & 0.004 & 0.403 & 0.067 & 0.025 \\
\hline \multicolumn{8}{|c|}{$\mathrm{O}_{3}$ treatments $^{\mathrm{x}}$} \\
\hline \multicolumn{4}{|c|}{ Gn $(2+3+4+5$ vs. $7+8+9+10)$} & 0.014 & 0.001 & 0.001 & 0.001 \\
\hline \multicolumn{4}{|c|}{ C vs. $L(1+6$ vs. $2+3+7+8)$} & 0.134 & 0.723 & - & 0.295 \\
\hline \multicolumn{4}{|c|}{ C vs. $\mathrm{H}(1+6$ vs. $4+5+9+10)$} & 0.176 & 0.403 & 0.769 & 0.010 \\
\hline \multicolumn{4}{|c|}{ L vs. $\mathrm{H}(2+3+7+8$ vs. $4+5+9+10)$} & 0.849 & 0.552 & - & 0.001 \\
\hline \multicolumn{4}{|c|}{ Time $(2+4+7+9$ vs. $3+5+8+10)$} & 0.305 & 0.289 & $0.437^{\mathrm{w}}$ & 0.009 \\
\hline \multicolumn{8}{|c|}{ Interactions } \\
\hline \multicolumn{4}{|c|}{$\mathrm{O}_{3} \times \mathrm{Gn}(4+5+7+8 \text { vs. } 2+3+9+10)^{\mathrm{v}}$} & 0.800 & 0.061 & $0.032^{\mathrm{u}}$ & 0.002 \\
\hline \multicolumn{4}{|c|}{ Time $\times$ Gn: $\mathrm{L}(2+8$ vs. $3+7)$} & 0.133 & 0.062 & - & 0.288 \\
\hline \multicolumn{4}{|c|}{ Time $\times$ Gn: $\mathrm{H}(4+10$ vs. $5+9)$} & 0.612 & 0.001 & - & 0.011 \\
\hline
\end{tabular}

${ }^{\mathrm{z}}$ Mean $\mathrm{O}_{3}$ levels were AMB (no added $\mathrm{O}_{3}$ ) $=9$ ppb day, 8 (spring) and 15 (fall) ppb night; LOW $=44$ ppb day, 46 (spring) and 49 (fall) ppb night; HIGH = 74 (spring) and 75 (fall) ppb day, 75 (spring) and 78 (fall) ppb night.

${ }^{\mathrm{y}}$ Only the control and high $\mathrm{O}_{3}$ treatments were sampled. The number of contrasts was restricted to five to control familywise error rate.

${ }^{\mathrm{x}}$ Each contrast compares individual treatments or combinations of treatments as noted by treatment numbers. $\mathrm{C}=$ control; $\mathrm{L}=$ low $\mathrm{O}_{3} ; \mathrm{H}=$ high $\mathrm{O}_{3} ; \mathrm{Gn}=$ genotype; Time $=$ day vs. day + night.

${ }^{\mathrm{w}}$ Value represents effect of time at high $\mathrm{O}_{3}(4+9$ vs. $5+10)$.

${ }^{\mathrm{v}}$ Compares response of genotypes to low and high $\mathrm{O}_{3}$, pooled across day and day + night treatment times.

${ }^{\mathrm{u}}$ Value represents interaction for $\mathrm{C}$ vs. $\mathrm{H}(1+9+10)$ vs. $(4+5+6)$.

$\mathrm{R} 123$ responds to $\mathrm{O}_{3}$ injury by increasing $R_{\mathrm{d}}$, which leads to higher $g_{\mathrm{sn}}$, and therefore, is better able to repair $\mathrm{O}_{3}$-induced injury than S156. However, our data do not support their hypothesis and show a greater relative increase in $g_{\text {sn }}$ for $\mathrm{S} 156$ than $\mathrm{R} 123$ in response to $\mathrm{O}_{3}$ exposure. Hoshika et al. (2013) also reported increased $g_{\mathrm{s}}$ measured after $10 \mathrm{~h}$ of darkness, relative to day $g_{\mathrm{s}}$, for $\mathrm{S} 156$ exposed to $150 \mathrm{ppb} \mathrm{O}_{3}$ for $1 \mathrm{~h}$. However, absolute $g_{\mathrm{s}}$ values did not actually increase relative to the control treatment and ranged from $\approx 21$ to 29 $\mathrm{mmol} \cdot \mathrm{m}^{-2} \cdot \mathrm{s}^{-1}$ among the $\mathrm{O}_{3}$ treatments for "well-watered" plants (see Figs. 3 and 5 therein). Therefore, their conclusions should be interpreted with caution. Other researchers also reported increased $g_{\text {sn }}$ for holly oak (Quercus ilex L.) following $\mathrm{O}_{3}$ exposure (Vitale et al., 2008). Measured at the whole-plant level, $\mathrm{O}_{3}$ exposure increased daily water use per unit leaf area for both R123 and S156, suggesting increased day and/or night $g_{\mathrm{s}}$ (Fiscus et al., 2012). Ozone impairs the ability of guard cells to close stomata (Caird et al., 2007; Paoletti and Grulke, 2010), providing another mechanism to explain elevated $g_{\text {sn }}$, in addition to enhanced maintenance respiration (Salvatori et al., 2013).
The time of $\mathrm{O}_{3}$ exposure had a significant effect on $g_{\text {sn }}$ only on 27 Oct. $(P=0.009)$, when rates were generally higher for the day than the day + night treatments (Table 6). However, the interaction of time $x$ genotype was also significant $(P=$ 0.011) for the high $\mathrm{O}_{3}$ treatment, reflecting a larger difference in $g_{\mathrm{sn}}$ between the day $\left(185.5 \mathrm{mmol} \cdot \mathrm{m}^{-2} \cdot \mathrm{s}^{-1}\right)$ and day + night $\left(112.5 \mathrm{mmol} \cdot \mathrm{m}^{-2} \cdot \mathrm{s}^{-1}\right)$ exposure times for S156 than R123 $\left(50.1\right.$ vs. $\left.43.1 \mathrm{mmol} \cdot \mathrm{m}^{-2} \cdot \mathrm{s}^{-1}\right)$. The opposite trend occurred for the significant time $\times$ genotype interaction on 7 May $(P=0.001)$, with greater $g_{\text {sn }}$ for S156 receiving the day + night timing (129.8 $\left.\mathrm{mmol} \cdot \mathrm{m}^{-2} \cdot \mathrm{s}^{-1}\right)$ than the day-only timing $\left(67.9 \mathrm{mmol} \cdot \mathrm{m}^{-2} \cdot \mathrm{s}^{-1}\right)$ at high $\mathrm{O}_{3}$. For R123, differences on 7 May in day and day + night rates at high $\mathrm{O}_{3}$ were small (i.e., 56.9 vs. 46.2 $\mathrm{mmol} \cdot \mathrm{m}^{-2} \cdot \mathrm{s}^{-1}$, respectively). Therefore, the impact of exposure time on $g_{\text {sn }}$ was significant but inconsistent for S156.

To date, few studies have investigated the effects of nighttime $\mathrm{O}_{3}$ exposure on $g_{\mathrm{sn}}$. Skärby et al. (1987) reported increased $g_{s n}$ in a single shoot $(n=1)$ of scots pine (Pinus sylvestris L.) exposed to $\mathrm{O}_{3}$ at night, relative to a shoot that was not exposed to $\mathrm{O}_{3}$. The inconclusive effects observed here may have been a sampling artifact because of variability in leaf injury levels and/ or differences in leaf maturity. Although data on $g_{\text {sn }}$ across leaf age are lacking, anatomically based estimates of conductance within mesophyll intercellular air spaces suggest that young S156 leaves allow greater gas exchange rates than adult leaves of both S156 and R123 (Villányi et al., 2013). In addition, epidermal cells in younger leaves of S156, those that developed after $\mathrm{O}_{3}$ exposure, stopped dividing earlier than cells from mature leaves. Consequently, cells expanded for a longer period of time, producing larger guard cells and stomatal apertures as a result of prior $\mathrm{O}_{3}$ exposure (Villányi et al., 2013). Therefore, conductance should ideally be measured on leaves of similar ages because $\mathrm{O}_{3}$ exposure affects anatomical development.

Leaf injury and repair also likely affect $g_{\text {sn }}$ (Salvatori et al., 2013). Therefore, it would be informative to measure leaves of different age and injury classes to determine whether the impact of $\mathrm{O}_{3}$ exposure on $g_{\text {sn }}$ is consistent. Other studies have focused on the first or second "fully expanded" trifoliate leaf from the top of the plant, shifting to younger leaves as the plant produces new growth over time (Elagöz et al., 2006; Flowers et al., 2007; Hoshika et al., 2013; Salvatori et al., 2013; Villányi et al., 2014). However, the definition of "fully expanded" does not appear uniform among studies. Importantly, leaf maturity has 
been shown to influence sensitivity to $\mathrm{O}_{3}$. Among different developmental stages, mature trifoliate leaves that had expanded to about $70 \%$ to $95 \%$ of full size were the most sensitive to $\mathrm{O}_{3}$ (i.e., in terms of visual foliar injury), relative to expanding leaves at $50 \%$ to $70 \%$ of full size, which had intermediate injury levels, and young leaves, which were the least sensitive (Lee and Bennett, 1982). Therefore, sampling the youngest "fully expanded" trifoliate leaf may not be an objective measure of how leaf gas exchange responds to $\mathrm{O}_{3}$ exposure.

\section{Conclusion}

Under control conditions, S156 and R123 produced similar yields by mass in Fall 2014 and Spring 2015 but not Fall 2015 (Tables 4 and 5). Yield mass ratios of S156:R123 ranged from 1.03 (Fall 2014) to 0.77 (Fall 2015) and were likely affected by environmental factors (Agathokleous et al., 2017). R123 produced significantly greater pod mass than S156 in the Fall 2015 control, and in all three trials, R123 had significantly greater mass yields than $\mathrm{S} 156$ under elevated daytime $\mathrm{O}_{3}$.

Nighttime $\mathrm{O}_{3}$ exposure alone, at $62 \mathrm{ppb}$, did not cause foliar injury and had no effect on the yields of S156 and R123. In combination with daytime $\mathrm{O}_{3}$ exposure, nighttime $\mathrm{O}_{3}$ treatment at up to $78 \mathrm{ppb}$ did not impact yield or show a consistent effect on $g_{\text {sn }}$. Because plants generally have a lower capacity to detoxify $\mathrm{O}_{3}$ at night, without a constant supply of metabolites from photosynthesis, an equivalent $\mathrm{O}_{3}$ dose may cause greater injury at night than during the day (Musselman and Minnick, 2000). Therefore, the "effective flux," which accounts for plant defense mechanisms and therefore overall sensitivity to $\mathrm{O}_{3}$, has the greatest potential to accurately predict $\mathrm{O}_{3}$ injury (Heath et al., 2009; Musselman et al., 2006). Recent work has demonstrated diurnal variation in plant sensitivity to $\mathrm{O}_{3}$ (Grantz, 2014; Grantz et al., 2013), but more research is required to establish the effects of nighttime $\mathrm{O}_{3}$ exposure.

Nighttime conductance measurements suggested that S156 and R123 have inherently different $g_{\text {sn }}$ rates and that cumulative $\mathrm{O}_{3}$ exposure can increase $g_{\mathrm{sn}}$ in both genotypes [i.e., results for 27 Oct. reflected the longest cumulative exposure (Table 6)]. However, exposure time (day vs. day + night) did not have a consistent effect on $g_{\mathrm{sn}}$. High $\mathrm{O}_{3}$ treatment caused a greater relative increase in $g_{\text {sn }}$ for $\mathrm{S} 156$ than R123, contrary to the results reported by Salvatori et al. (2013). Notably, elevated $g_{\text {sn }}$ may create a positive feedback when nighttime $\mathrm{O}_{3}$ levels are high, increasing $\mathrm{O}_{3}$ flux into the leaf (Salvatori et al., 2013). However, different sampling strategies and potential variation of $g_{\text {sn }}$ with leaf maturity and injury confound results to date. Future experiments should test a larger range of night $\mathrm{O}_{3}$ concentrations, in combination with daytime exposure, on the physiology and yield of S156 and R123. Improved understanding of how $g_{\text {sn }}$ varies with leaf characteristics, as well as temporally through the night, will help predict the effects of elevated nighttime $\mathrm{O}_{3}$.

\section{Literature Cited}

A.S.L. \& Associates. n.d. The importance of nighttime ozone exposures for vegetation effects. 16 Feb. 2017. <http://www.aslassociates.com/nighttime_exposure_vegetation.htm>.

Agathokleous, E., C.J. Saitanis, K.O. Burkey, G. Ntatsi, V. Vougeleka, A.M. Mashaheet, and A. Pallides. 2017. Application and further characterization of the snap bean S156/R123 ozone biomonitoring system in relation to ambient air temperature. Sci. Total Environ. 580:1046-1055.

Ashmore, M.R. 2005. Assessing the future global impacts of ozone on vegetation. Plant Cell Environ. 28:949-964.

Baier, M., A. Kandlbinder, D. Golldack, and K-J. Dietz. 2005. Oxidative stress and ozone: Perception, signalling and response. Plant Cell Environ. 28:1012-1020.

Booker, F., R. Muntifering, M. Mcgrath, K. Burkey, D. Decoteau, E. Fiscus, W. Manning, S. Krupa, A. Chappelka, and D. Grantz. 2009. The ozone component of global change: Potential effects on agricultural and horticultural plant yield, product quality and interactions with invasive species. J. Integr. Plant Biol. $51: 337-351$.

Brown, K.A. and T.M. Roberts. 1988. Effects of ozone on foliar leaching in Norway spruce (Picea abies L. Karst): Confounding factors due to NOx production during ozone generation. Environ. Pollut. 55:55-73.

Burkey, K.O., F.L. Booker, E.A. Ainsworth, and R.L. Nelson. 2012. Field assessment of a snap bean ozone bioindicator system under elevated ozone and carbon dioxide in a free air system. Environ. Pollut. 166:167-171.

Burkey, K.O., J.E. Miller, and E.L. Fiscus. 2005. Assessment of ambient ozone effects on vegetation using snap bean as a bioindicator species. J. Environ. Qual. 34:1081-1086.

Bytnerowicz, A., M. Tran, and P. Anderson. 1995. Effects of charcoal air filtration and ozone generation on concentrations of some $\mathrm{N}$ and $\mathrm{S}$ compounds in open-top field chambers. Atmos. Environ. 29:13551358.

Caird, M.A., J.H. Richards, and L.A. Donovan. 2007. Nighttime stomatal conductance and transpiration in $\mathrm{C} 3$ and $\mathrm{C} 4$ plants. Plant Physiol. 143:1-10.

Conklin, P.L. and C. Barth. 2004. Ascorbic acid, a familiar small molecule intertwined in the response of plants to ozone, pathogens, and the onset of senescence. Plant Cell Environ. 27:959-970.

Dawson, T.E., S.S.O. Burgess, K.P. Tu, R.S. Oliveira, L.S. Santiago, J.B. Fisher, K.A. Simonin, and A.R. Ambrose. 2007. Nighttime transpiration in woody plants from contrasting ecosystems. Tree Physiol. 27:561-575.

Easlon, H.M. and J.H. Richards. 2009. Photosynthesis affects following night leaf conductance in Vicia faba. Plant Cell Environ. 32:58-63.

Elagöz, V., S.S. Han, and W.J. Manning. 2006. Acquired changes in stomatal characteristics in response to ozone during plant growth and leaf development of bush beans (Phaseolus vulgaris L.) indicate phenotypic plasticity. Environ. Pollut. 140:395-405.

Emberson, L.D., G. Wieser, and M.R. Ashmore. 2000. Modelling of stomatal conductance and ozone flux of Norway spruce: Comparison with field data. Environ. Pollut. 109:393-402.

Feng, Z. and K. Kobayashi. 2009. Assessing the impacts of current and future concentrations of surface ozone on crop yield with metaanalysis. Atmos. Environ. 43:1510-1519.

Fiscus, E.L., F.L. Booker, W. Sadok, and K.O. Burkey. 2012. Influence of atmospheric vapour pressure deficit on ozone responses of snap bean (Phaseolus vulgaris L.) genotypes. J. Expt. Bot. 63:2557-2594.

Flowers, M.D., E.L. Fiscus, K.O. Burkey, F.L. Booker, and J-J.B. Dubois. 2007. Photosynthesis, chlorophyll fluorescence, and yield of snap bean (Phaseolus vulgaris L.) genotypes differing in sensitivity to ozone. Environ. Expt. Bot. 61:190-198.

Forlani, A., G. Merola, and M. Fagnano. 2005. Ozone effects on vegetation in three different localities of Campania region (southern Italy). Fresenius Environ. Bull. 14:478-483.

Goknur, A.B. and T.W. Tibbitts. 2001. Association of dark opening of stomata with air pollution sensitivity of Irish potatoes. J. Amer. Soc. Hort. Sci. 126:37-43.

Grantz, D.A. 2014. Diel trend in plant sensitivity to ozone: Implications for exposure- and flux-based ozone metrics. Atmos. Environ. 98:571-580. 
Grantz, D.A., H. Vu, R.L. Heath, and K.O. Burkey. 2013. Demonstration of a diel trend in sensitivity of Gossypium to ozone: A step toward relating $\mathrm{O}_{3}$ injury to exposure or flux. J. Expt. Bot. 64:17031713.

Gravano, E., F. Bussotti, R.J. Strasser, M. Schaub, K. Novak, J. Skelly, and C. Tani. 2004. Ozone symptoms in leaves of woody plants in open-top chambers: Ultrastructural and physiological characteristics. Physiol. Plant. 121:620-633.

Guidi, L., M. Tonini, and G.F. Soldatini. 2000. Effects of high light and ozone fumigation on photosynthesis in Phaseolus vulgaris. Plant Physiol. Biochem. 38:717-725.

Günthardt-Goerg, M.S. 1996. Different responses to ozone of tobacco, poplar, birch, and alder. J. Plant Physiol. 148:207-214.

Harris, G.W., W.P.L. Carter, A.M. Winer, R.A. Graham, and J.N. Pitts, Jr. 1982. Studies of trace non-ozone species produced in a corona discharge ozonizer. J. Air Pollut. Control Assoc. 32:274276.

Heagle, A.S., J.E. Miller, K.O. Burkey, G. Eason, and W.A. Pursley. 2002. Growth and yield responses of snap bean to mixtures of carbon dioxide and ozone. J. Environ. Qual. 31:2008-2014.

Heath, R.L., A.S. Lefohn, and R.C. Musselman. 2009. Temporal processes that contribute to nonlinearity in vegetation responses to ozone exposure and dose. Atmos. Environ. 43:29192928.

Heck, W.W., R.B. Philbeck, and J.A. Dunning. 1978. A continuous stirred tank reactor (CSTR) system for exposing plants to gaseous air contaminants: Principles, specifications, construction, and operation. U.S. Dept. Agr., Agr. Res. Serv., U.S. Govt. Printing Office 1978771-106/10.

Hoshika, Y., K. Omasa, and E. Paoletti. 2013. Both ozone exposure and soil water stress are able to induce stomatal sluggishness. Environ. Expt. Bot. 88:19-23.

International Cooperative Programme on Effects of Air Pollution on Natural Vegetation and Crops. 2012. Yield response and ozone injury on Phaseolus vulgaris: Experimental protocol. 16 Feb. 2017. $<$ http://icpvegetation.ceh.ac.uk/manuals/documents/ICPVegetationPhaseolusvulgarisprotocol2012_Final.pdf $>$.

Kangasjärvi, J., P. Jaspers, and H. Kollist. 2005. Signalling and cell death in ozone-exposed plants. Plant Cell Environ. 28:10211036.

Langebartels, C., H. Wohlgemuth, S. Kschieschan, S. Grün, and H. Sandermann. 2002. Oxidative burst and cell death in ozone-exposed plants. Plant Physiol. Biochem. 40:567-575.

Lee, E.H. and J.H. Bennett. 1982. Superoxide dismutase: A possible protective enzyme against ozone injury in snap beans (Phaseolus vulgaris L.). Plant Physiol. 69:1444-1449.

Lee, E.H. and W.E. Hogsett. 1999. Role of concentration and time of day in developing ozone exposure indices for a secondary standard. J. Air Waste Mgt. Assoc. 49:669-681.

Lefohn, A.S., J.A. Laurence, and R. Kohut. 1988. A comparison of indices that describe the relationship between exposure to ozone and reduction in the yield of agricultural crops. Atmos. Environ. 22:1229-1240.

Lefohn, A.S. and V.C. Runeckles. 1987. Establishing standards to protect vegetation-Ozone exposure/dose considerations. Atmos. Environ. 21:561-568.

Lentner, M. and T. Bishop. 1993. Experimental design and analysis. 2nd ed. Valley Book Co., Blacksburg, VA.

Marini, R.P. 2003. Approaches to analyzing experiments with factorial arrangements of treatments plus other treatments. HortScience 38:117-120.

Matyssek, R., M.S. Gunthardt-Goerg, S. Maurer, and T. Keller. 1995. Nighttime exposure to ozone reduces whole-plant production in Betula pendula. Tree Physiol. 15:159-165.

Mortensen, L. and H.E. Jørgensen. 1996. Responses of spring wheat (Triticum aestivum $\mathrm{L}$.) to ozone produced by either electric discharge and dry air or by UV-lamps and ambient air. Environ. Pollut. 93:121127.
Musselman, R.C., A.S. Lefohn, W.J. Massman, and R.L. Heath. 2006. A critical review and analysis of the use of exposure- and flux-based ozone indices for predicting vegetation effects. Atmos. Environ. 40:1869-1888.

Musselman, R.C. and T.J. Minnick. 2000. Nocturnal stomatal conductance and ambient air quality standards for ozone. Atmos. Environ. 34:719-733.

Olszyk, D.M., P.J. Dawson, C.L. Morrison, and B.K. Takemoto. 1990. Plant response to nonfiltered air vs. added ozone generated from dry air or oxygen. J. Air Waste Mgt. Assoc. 40:77-81.

Orendovici, T. 2005. The response of black cherry and hybrid poplar to ozone under varying environmental conditions. Pennsylvania State Univ., University Park, PA, PhD Diss.

Orendovici-Best, T., J.M. Skelly, and D.D. Davis. 2010. Spatial and temporal patterns of ground-level ozone within north-central Pennsylvania forests. Northeast. Nat. 17:247-260.

Orvar, B.L., J. McPherson, and B.E. Ellis. 1997. Pre-activating wounding response in tobacco prior to high-level ozone exposure prevents necrotic injury. Plant J. 11:203-212.

Paoletti, E. and N.E. Grulke. 2010. Ozone exposure and stomatal sluggishness in different plant physiognomic classes. Environ. Pollut. 158:2664-2671.

Pell, E.J., C.D. Schlagnhaufer, and R.N. Arteca. 1997. Ozone-induced oxidative stress: Mechanisms of action and reaction. Physiol. Plant. 100:264-273.

Reich, P.B. and R.G. Amundson. 1985. Ambient levels of ozone reduce net photosynthesis in tree and crop species. Science 230:566570.

Reinert, R.A. and G. Eason. 2000. Genetic control of $\mathrm{O}_{3}$ sensitivity in a cross between two cultivars of snap bean. J. Amer. Soc. Hort. Sci. 125:222-227.

Ryan, W.F., C.A. Piety, and E.D. Luebehusen. 2000. Air quality forecasts in the mid-Atlantic region: Current practice and benchmark skill. Weather Forecast. 15:46-60.

Salvatori, E., L. Fusaro, S. Mereu, A. Bernardini, G. Puppi, and F. Manes. 2013. Different $\mathrm{O}_{3}$ response of sensitive and resistant snap bean genotypes (Phaseolus vulgaris L.): The key role of growth stage, stomatal conductance, and PSI activity. Environ. Expt. Bot. 87:79-91.

Schraudner, M., W. Moeder, C. Wiese, W.V. Camp, D. Inzé, C. Langebartels, and H. Sandermann, Jr. 1998. Ozone-induced oxidative burst in the ozone biomonitor plant tobacco Bel W3. Plant J. 16:235-245.

Skärby, L., E. Troeng, and C. Boström. 1987. Ozone uptake and effects on transpiration, net photosynthesis, and dark respiration in scots pine. For. Sci. 33:801-808.

Stull, R.B. 1988. An introduction to boundary layer meteorology. 1st ed. Kluwer, Dordrecht, The Netherlands.

Temple, P. 1991. Variations in responses of dry bean (Phaseolus vulgaris) cultivars to ozone. Agr. Ecosyst. Environ. 36:1-11.

U.S. Environmental Protection Agency. 2013. 2013 Final report: Integrated science assessment of ozone and related photochemical oxidants. U.S. Environ. Protection Agency EPA/600/R-10/076F.

U.S. Environmental Protection Agency. 2015. National ambient air quality standards for ozone; Final rule. 80 FR 65291. 16 Feb. 2017. $<$ https://www.federalregister.gov/documents/2015/10/26/201526594/national-ambient-air-quality-standards-for-ozone $>$.

Villányi, V., H. Déri, E.R. Péli, and Z. Csintalan. 2013. Differences in histological and physiological traits of ozone sensitive and resistant bean strains. Cent. Eur. J. Biol. 8:386-397.

Villányi, V., Z. Ürmös, B. Turk, F. Batič, and Z. Csintalan. 2014. Photosynthesis of ozone-sensitive and -resistant Phaseolus vulgaris genotypes under ambient ozone and moderate heat stress. Photosynthetica 52:604-613.

Vitale, M., E. Salvatori, F. Loreto, S. Fares, and F. Manes. 2008. Physiological responses of Quercus ilex leaves to water stress and acute ozone exposure under controlled conditions. Water Air Soil Pollut. 189:113-125. 
Wilkinson, S. and W.J. Davies. 2010. Drought, ozone, ABA and ethylene: New insights from cell to plant to community. Plant Cell Environ. 33: 510-525.

Winner, W.E., A.S. Lefohn, I.S. Cotter, C.S. Greitner, J. Nellessen, L. R. McEvoy, Jr., R.L. Olson, C.J. Atkinson, and L.D. Moore. 1989. Plant responses to elevational gradients of $\mathrm{O}_{3}$ exposures in Virginia. Proc. Natl. Acad. Sci. USA 86:8828-8832.
Wohlgemuth, H., K. Mittelstrass, S. Kschieschan, J. Bender, H-J. Weigel, K. Overmyer, J. Kangasjärvi, H. Sandermann, and C. Langebartels. 2002. Activation of an oxidative burst is a general feature of sensitive plants exposed to the air pollutant ozone. Plant Cell Environ. 25:717-726.

World Health Organization. 2006. Air quality guidelines: Global update 2005: Particulate matter, ozone, nitrogen dioxide, and sulfur dioxide. WHO, Copenhagen, Denmark. 